\title{
Bird Bone Flageolet from the Walter Bell Site (41SB50) at Lake Sam Rayburn, Sabine County, Texas
}

Timothy K. Perttula

Heritage Research Center, Stephen F. Austin State University

Follow this and additional works at: https://scholarworks.sfasu.edu/ita

Part of the American Material Culture Commons, Archaeological Anthropology Commons, Environmental Studies Commons, Other American Studies Commons, Other Arts and Humanities Commons, Other History of Art, Architecture, and Archaeology Commons, and the United States History Commons

Tell us how this article helped you.

This Article is brought to you for free and open access by the Center for Regional Heritage Research at SFA ScholarWorks. It has been accepted for inclusion in Index of Texas Archaeology: Open Access Gray Literature from the Lone Star State by an authorized editor of SFA ScholarWorks. For more information, please contact cdsscholarworks@sfasu.edu. 


\section{Bird Bone Flageolet from the Walter Bell Site (41SB50) at Lake Sam Rayburn,}

Sabine County, Texas

\section{Creative Commons License}

\section{(c) (1) \&}

This work is licensed under a Creative Commons Attribution-NonCommercial 4.0 International License 


\title{
Bird Bone Flageolet from the Walter Bell Site (41SB50) at Lake Sam Rayburn, Sabine County, Texas
}

\author{
Timothy K. Perttula
}

\section{INTRODUCTION}

The Walter Bell site (41SB50) at Lake Sam Rayburn in the Neches-Angelina river basins in the deep East Texas Pineywoods was excavated by an National Park Service team in 1957 (Jelks 1965:53-69). This was a small prehistoric Caddo farmstead or hamlet with two circular houses, a portion of a third house in the area of House 2, midden deposits, and six burials (Figure 1). Based on the kinds of artifacts found at the site (i.e., clay elbow pipes, a high proportion of brushed utility ware sherds from Broaddus Brushed vessels, and lower proportions of Pineland Punctated-Incised vessel sherds), the Walter Bell site was apparently occupied after ca. A.D. 1450-1500, in the Late Caddo period (see Middlebrook 1994:26-29 and Figure 4, 1997; Perttula et al. 2009:22).

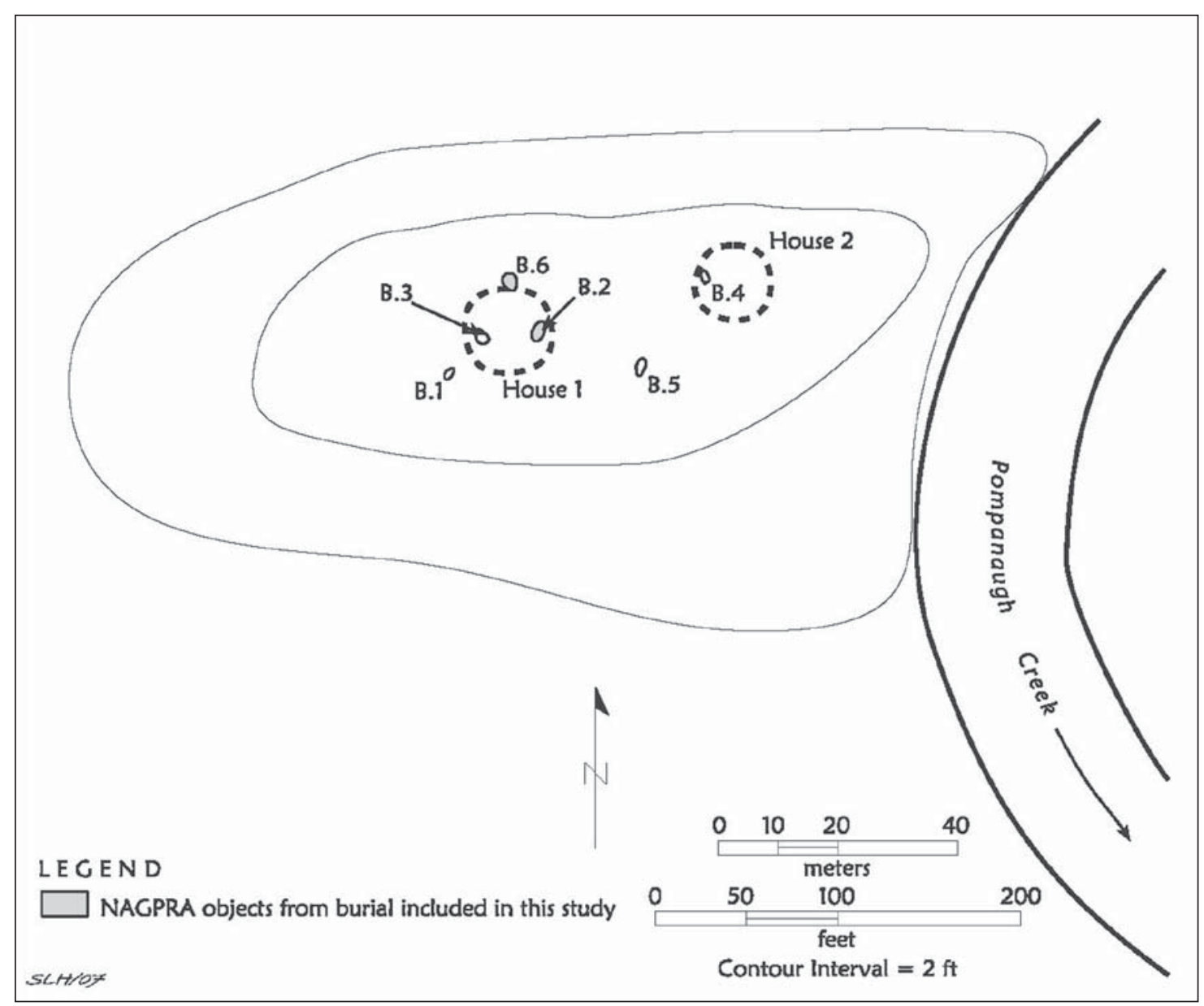

Figure 1. Map of the Walter Bell site and the locations of Houses 1 and 2 and Burials 1-6. 
Four of the burials (Burials 1-3 and 6) were in close association (either inside the house and underneath the house floor) with House 1, one (Burial 4) was inside House 2, and Burial 5 was in an open area, possibly a courtyard or work area between the two Caddo houses. Funerary offerings placed with the deceased included ceramic vessels, Perdiz arrow points, conch shell beads, deer ulna tools and deer food offerings, mussel shells, and engraved bird bone flageolets.

\section{Bird Bone Flageolet}

The bird bone flute or flageolet is from Burial 6, a middle-aged adult, probably a Caddo male (Jelks 1965:65), found beneath the north wall of House 1. It is in the collections of the Texas Archeological Research Laboratory at The University of Texas at Austin. The individual was flexed, and was laid on its right side, with the head to the northwest. The bird bone flageolet was placed in the area of the hands, with one end extending beneath the mandible. Other bird bone flageolets have been found with Burials 3 and 5 at the Walter Bell site, and in a Late Caddo period burial (Burial 2) at the Wylie Price site (41SA94).

The flageolets were made from the long bones of large birds, probably a crane or turkey, and they have a single stop hole near one end of the flute (Figure 2). The flageolet from Burial 6 has a $12.3 \mathrm{~cm}$ long decorated area that begins at the stop hole; the flute is $25.0 \mathrm{~cm}$ in total length. The decoration consists of a series of three intersecting hatched diagonal engraved zones, and the hatched zones are approximately $12.7 \mathrm{~mm}$ in height along the body of the flute (Figure 2a-b).

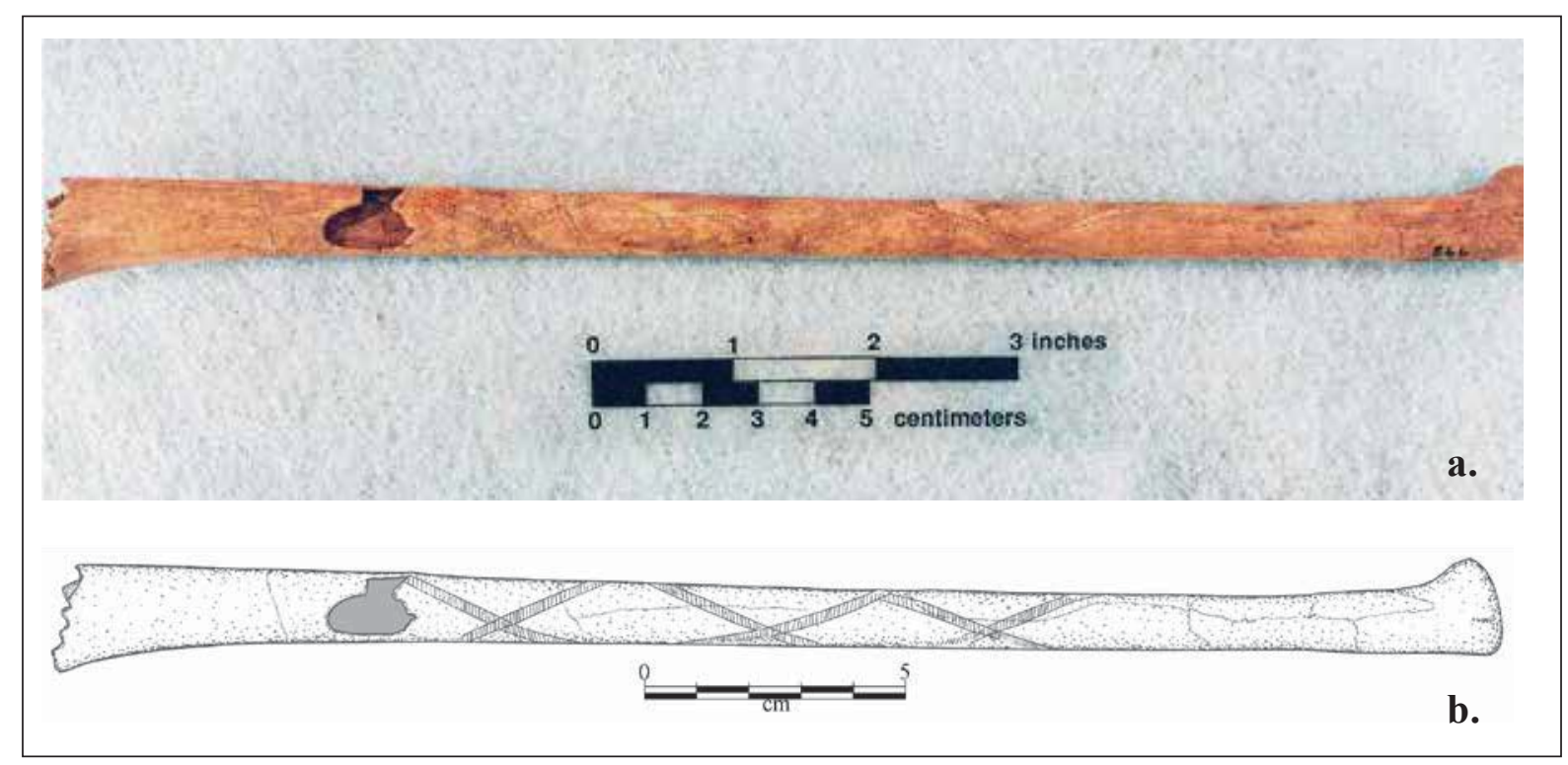

Figure 2. Bird bone flageolet from Burial 6 at the Walter Bell site: a, photograph; $b$, drawing of the decorative elements on the bird bone flageolet by Lance Trask.

A similar decorated bird bone flageolet was recovered from an archaeological site in the Woodville, Texas, area, ca. $40 \mathrm{~km}$ or more to the southwest of the Walter Bell site, in the Neches River basin (Figure 3). This flageolet is decorated with six upper and lower hatched triangle elements that begin by the stop hole.

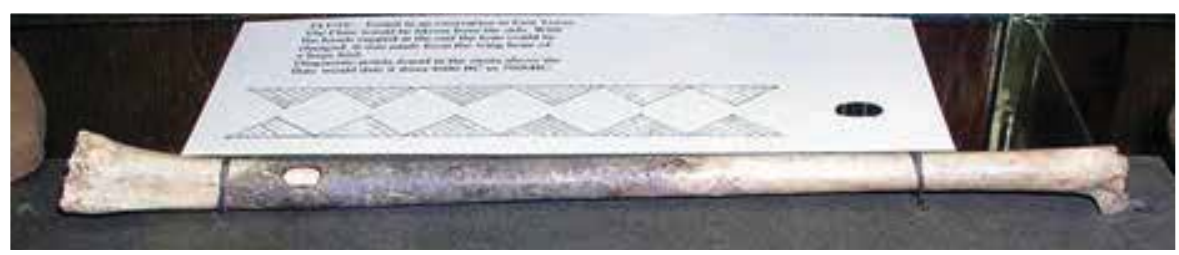

Figure 3. Bird bone flageolet in the Heritage Village, Woodville, Texas (http:// www.fluteopedia.com/dev_flutes_northamerica.htm). 
Other bird bone flageolets have been found in aboriginal sites along the Texas Gulf Coast. This includes four engraved flageolets made from whooping crane ulnae in ca. A.D. 1400-1750 contexts at the Mitchell Ridge site (41GV66) on Galveston Island (Ricklis 1994:445, 2004:Figure 6.17a) (Figure 4), in a burial at the Harris County Boys School site (Aten et al. 1976), and the Redtail site (41HR581) (Gadus and Howard 1990). Engraved bird bone flutes have also been recovered in a flexed burial at the Miller site (16CM30) in Southwest Louisiana (Ricklis 1994:448 and Figure 11.6), and flute fragments in post-A.D. 1000 contexts at 41BO50 in the Brazos River delta (Aten 1983:263); the Early Historic bird bone flutes from the Mitchell Ridge site are not engraved, however. Ricklis (personal communication, April 13, 2015) suggests that these bird bone flutes may have been made by Atakapan speakers (i.e., Bidai, Akokisa, and Atakapa proper) from the Texas and Southwest Louisiana Gulf Coast, and perhaps exchanged to Caddo peoples living in the Angelina River basin.

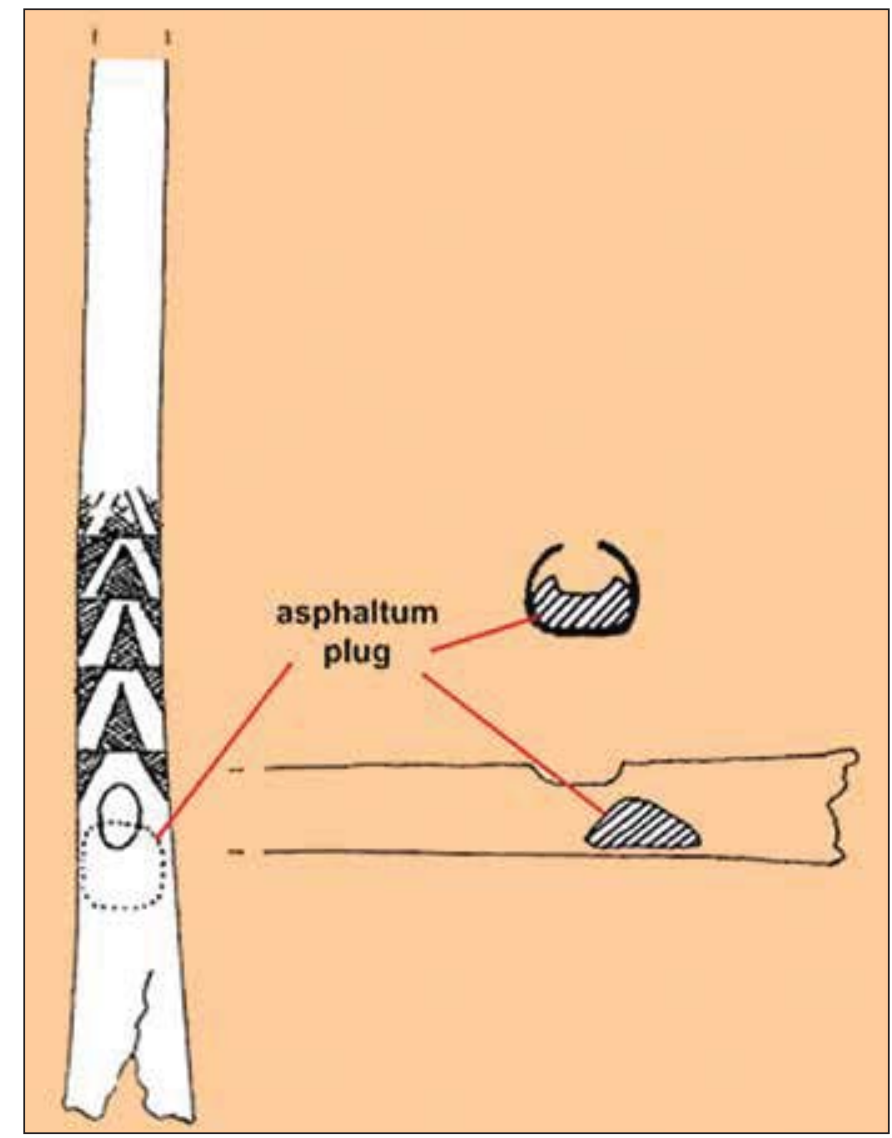

Figure 4. Whooping crane bone flute from the Mitchell Ridge site (Ricklis 1994:Figure 11.5).

\section{SUMMARY AND CONCLUSIONS}

Bone flutes and whistles that produced sounds and music are widely distributed in archaeological sites in eastern North America (see Martin 1976), but are rare occurrences on East Texas Caddo sites and Texas Gulf Coastal aboriginal populations. The production of sounds and music by humans is believed to be a powerful means by which people generate feelings and emotions, and promote group identities (e.g., Brown 2000; Falk 2001; Honing and Ploeger 2012; Morley 2013). In Caddo sites, "birds and their symbolic representations...were an important part of Caddo ritual and ceremony" (Gadus 2013:230), particularly to links with the upper world of Caddo beliefs "where feathered beings dwell." Thus, the Caddo individual buried in a grave at the Walter Bell site after ca. A.D. 1450-1500 with an engraved bird bone flageolet associated 
with upper world spiritual beliefs and with the production of music may have been a socially important person who participated in collective ceremonies in the local Caddo community.

\section{ACKNOWLEDGMENTS}

I thank Robert A. Ricklis for his comments about bird bone flageolets from Texas and Louisiana sites. Figure 1 was prepared by Sandra Hannum, Bo Nelson took the Figure 2a photograph, and Lance Trask prepared Figure $2 \mathrm{~b}$. The source of Figure 4 is the Texas Beyond History website prepared by the Texas Archeological Research Laboratory at The University of Texas.

\section{REFERENCES CITED}

Aten, L. E.

1983 Indians of the Upper Texas Coast. Academic Press, New York.

Aten, L. E., C. K. Chandler, A. B. Wesolowsky, and R. M. Malina

1976 Excavations at the Harris County Boys School Cemetery. Special Publication No. 3. Texas Archeological Society, San Antonio.

Brown, S.

2000 Evolutionary models of music: from sexual selection to group selection. In Perspectives in Ethology: Evolution, Culture, and Behavior, Vol. 13, edited by F. Tonneau and N. S. Thompson, pp. 231-281. Springer, New York.

Falk, D.

2001 Hominid brain evolution and the origins of music. In The Origins of Music, edited by N. L. Wallin, B. Merker, and S. Brown, pp. 197-216. MIT Press, Cambridge.

Gadus, E. F.

2013 Twisted Serpents and Fierce Birds: Structural Variation in Caddo Engraved Ceramic Bottle Motifs. Bulletin of the Texas Archeological Society 84:213-245.

Gadus, E. F. and M. A. Howard

1990 Hunter-Fisher-Gatherers on the Upper Texas Coast: Archeological Investigations at the Peggy Lake Disposal Area, Harris County, Texas. Reports of Investigations No. 74. Prewitt \& Associates, Inc., Austin.

Honing, H. and A. Ploeger

2012 Cognition and the evolution of music: pitfalls and prospects. Topics in Cognitive Science (2012):1-12.

Jelks, E. B.

1965 The Archeology of McGee Bend Reservoir, Texas. Ph.D. dissertation, Department of Anthropology, The University of Texas at Austin.

Martin, K. L. H.

1976 Bone Flutes and Whistles from Archaeological Sites in Eastern North America. Master's thesis, Department of Anthropology, University of Tennessee, Knoxville.

Middlebrook, T. A.

1994 An Update of Archaeological Investigations at the Tyson Site. Journal of Northeast Texas Archaeology $3: 1-36$.

1997 The Caddoan Occupation of the Attoyac and Angelina River Basins in the Middle Caddoan Period. Journal of Northeast Texas Archaeology 10:36-40. 
Morley, I.

2013 The Prehistory of Music: Human Evolution, Archaeology and the Origins of Musicality. Oxford University Press, Oxford.

Perttula, T. K., R. Cast, B. Gonzalez, and B. Nelson

2009 Documentation of Unassociated and Culturally Unidentifiable Funerary Objects in the U.S. Army Corps of Engineers, Fort Worth District Collections Housed at the Texas Archeological Research Laboratory at the University of Texas at Austin. Special Publication No. 13. Friends of Northeast Texas Archaeology, Pittsburg and Austin.

Ricklis, R. A.

1994 Aboriginal Life and Culture on the Upper Texas Coast: Archaeology at the Mitchell Ridge Site, 41GV66, Galveston Island. Coastal Archaeological Studies, Corpus Christi.

2004 The Archeology of the Native American Occupation of Southeast Texas. In The Prehistory of Texas, edited by T. K. Perttula, pp. 181-202. Texas A\&M University Press, College Station. 